症例

制御不能の消化管出血を主体とした結節性多発動脈炎の 1 例 富山赤十字病院外科

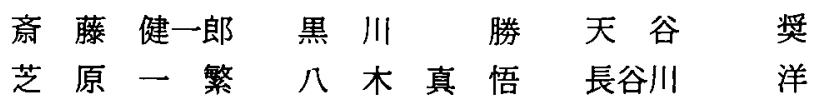

症例は65歳, 男性．腹部膨満感，嘔気を主訴に受診した。上部消化管内視鏡で十二指 腸下行脚より肛門側に連続するびらん，潰湟，出血を認めた．腹部 CT では広範囲の小 腸炎を認めた，十二指腸粘膜からの生検では特異的な所見は認めず，診断確定には至ら なかった．保存的加療を行うも 2 度の大量下血を認め，3 度目の大量下血の際に血管造 影検査を施行し, 回結腸動脈の回腸末梢枝からの出血を確認しえたため TAE を施行し た。しかし 4 度目の下血を生じたため同部回腸の部分切除を施行した。切除標本にて中 〜小動脈を主体の壊死性血管炎を認め，結節性多発動脈炎の診断を得た。ステロイドパ ルス療法を開始し，併発した腎不全には CHDF を行い治療したが，下血は治まらず，入 院36日目（術後11日目）に永眠された，治療抵抗性の出血性腸炎に遭遇した場合，結節 性多発動脈炎などの血管炎の可能性を念頭におき，より早期の診断および治療が肝要と 考えられた。

索引用語：結節性多発動脈炎, 消化管出血, 消化管病変

\section{緒言}

結節性多発動脈炎 (polyarteritis nodosa：以下 PN）は全身の小・中径動脈を侵す壊死性血管炎であ り, 病変が消化管の動脈に及ぶと出血や壊死, 穿孔な どの致命的な病態に宿ることがある(1 文. 今回われわ れは制御不能の消化管出血を主体とした結節性多発動 脈炎の 1 例を経験したので報告する.

\section{症例}

患者：65歳, 男性.

主訴：腹満, 嘔気。

既往歴：尿管結石で入院. 急性腰痛症で 2 回入院.

家族歴：特記すべきことなし.

嗜好品・常用菜：特になし。

現病歴：平成17年 8 月中旬より上記主訴出現した。 前医受診し, 腹部超音波検查にて幽門狭窄疑いで当院 紹介となった. 上部消化管内視鏡検査で十二指腸下行 脚より肛門側に連続するびらん, 謴瘍, 出血を認め, 精查加療目的に入院となった。

2006年 4 月 3 日受付 2006 年 6 月27日採用

〈所属施設住所〉

テ930-0859 富山市牛島本町 $2-1-58$
入院時現症: 身長 $162.5 \mathrm{~cm}$, 体重 $71.0 \mathrm{~kg}$, 体温 $36.4^{\circ} \mathrm{C}$, 血圧 $171 / 102 \mathrm{mmHg}$, 脈拍 $66 / \mathrm{min}$. 賀血, 黄㾝 は認めなかった。四肢浮腫も認めなかった。腹部膨満, 上腹部に軽度圧痛を認めた。

入院時検査所見：検血では白血球数 $18,400 / \mu 1$, $\mathrm{CRP} 14.2 \mathrm{mg} / \mathrm{dl}$ と上昇し, 生化学検査では BUN 79 $\mathrm{mg} / \mathrm{dl}, \mathrm{Cr} 1.9 \mathrm{mg} / \mathrm{dl}$ と上昇を認めた。検尿では蛋白 $(十)$, 潜血 $( \pm$ )であった（表 1$)$.

腹部単純 $\mathrm{X}$ 線検查：胃内に著明なガス像を認めた。 腹部超音波検査：胃内の残渣と胃の拡張を認めた。

上部消化管内視鏡検査：胃体下部から前庭部にびら んが散在していた。 十二指腸下行脚には全域にわたり 全周性に多数のびらん・潰瘍を認めた，粘膜は著明に 発赤, 浮腫状であり, 所々に出血を認めた（図 1$)$.

入院後経過：急性出血性胃腸炎にて入院し絶飲食と し補液を行った。入院 4 日目の腹部〜骨盤部 CT 検查 ては広沉な小腸の壁肥厚を認めた(図 $2 \mathbf{a}, \mathbf{b})$. 保存 的加療を行うも, 改善は認めなかった。各種便培養や 抗体検査など行うも有意な所見は得られなかった（表 1). 入院 9 日目に再度上部消化管内視鏡検查を施行し

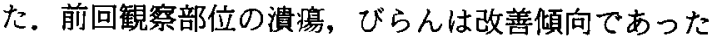
がより深部の十二指腸には凝血塊が残存していた（図 
表 1 入院時検査成樍

\begin{tabular}{|c|c|c|c|c|c|c|c|}
\hline WBC & 18,400 & $\mid \mu \mathrm{l}$ & $\mathrm{Cr}$ & \multicolumn{2}{|c|}{$1.9 \mathrm{mg} / \mathrm{dl}$} & \multicolumn{2}{|l|}{ （検尿） } \\
\hline $\mathrm{RBC} 4$. & $.69 \times 10^{6}$ & $|\mu|$ & BUN & \multirow{2}{*}{\multicolumn{2}{|c|}{$\begin{array}{r}79 \mathrm{mg} / \mathrm{dl} \\
135 \mathrm{mEq} / 1\end{array}$}} & 黄褐色 & \\
\hline $\mathrm{Hb}$ & 15.8 & $\mathrm{~g} / \mathrm{dl}$ & $\mathrm{Na}$ & & & 混濁 & $(-)$ \\
\hline $\mathrm{Ht}$ & 43.8 & $\%$ & $\mathrm{~K}$ & \multicolumn{2}{|c|}{$4.2 \mathrm{mEq} / 1$} & 比重 & 1.024 \\
\hline Plt & $193 \times 10^{3}$ & $/ \mu 1$ & $\mathrm{Cl}$ & \multicolumn{2}{|c|}{$97 \mathrm{mEq} / 1$} & $\mathrm{pH}$ & 5.0 \\
\hline GOT & 16 & $\mathrm{IU} / 1$ & & & & 蛋白 & $(+)$ \\
\hline GPT & 18 & $\mathrm{IU} / 1$ & \multicolumn{2}{|c|}{ アニサキス抗体 } & $(-)$ & 糖 & $(-)$ \\
\hline ALP & 247 & $\mathrm{IU} / 1$ & \multicolumn{2}{|c|}{ 赤痢アメーバ } & $(-)$ & ウロビリノーゲン & $(+)$ \\
\hline$\gamma$-GTP & 119 & $\mathrm{IU} / 1$ & \multicolumn{2}{|c|}{ ANA } & $<40$ & ビリルビン & $(-)$ \\
\hline T-Bil & 0.8 & $\mathrm{mg} / \mathrm{dl}$ & \multicolumn{2}{|c|}{ HOMOGENE } & $<40$ & アセトン & $(-)$ \\
\hline CPK & 70 & $\mathrm{IU} / 1$ & \multicolumn{2}{|c|}{ SPECKLED } & $<40$ & 潜血 & $( \pm)$ \\
\hline $\mathrm{LDH}$ & 172 & $\mathrm{IU} / 1$ & \multicolumn{2}{|c|}{ NUCLEOLA } & $<40$ & 亜硝酸 & $(-)$ \\
\hline Amy & 34 & $\mathrm{IU} / 1$ & \multicolumn{2}{|c|}{ CENTROME } & $<40$ & 白血球反応 & $(-)$ \\
\hline $\mathrm{TP}$ & 5.8 & $\mathrm{~g} / \mathrm{dl}$ & \multicolumn{2}{|c|}{ PERIPHER } & $<40$ & & \\
\hline \multirow[t]{3}{*}{ CRP } & \multirow{3}{*}{\multicolumn{2}{|c|}{$14.2 \mathrm{mg} / \mathrm{dl}$}} & \multicolumn{2}{|c|}{ C-ANCA } & $<10$ & （便培榣） & \\
\hline & & & \multirow{2}{*}{\multicolumn{2}{|c|}{$\begin{array}{l}\text { MPO-ANCA } \\
\text { カルジオ ICG }\end{array}$}} & $<10$ & Klebsiella sp. & $(2+)$ \\
\hline & & & & & 1 & E. coli & $(2+)$ \\
\hline
\end{tabular}
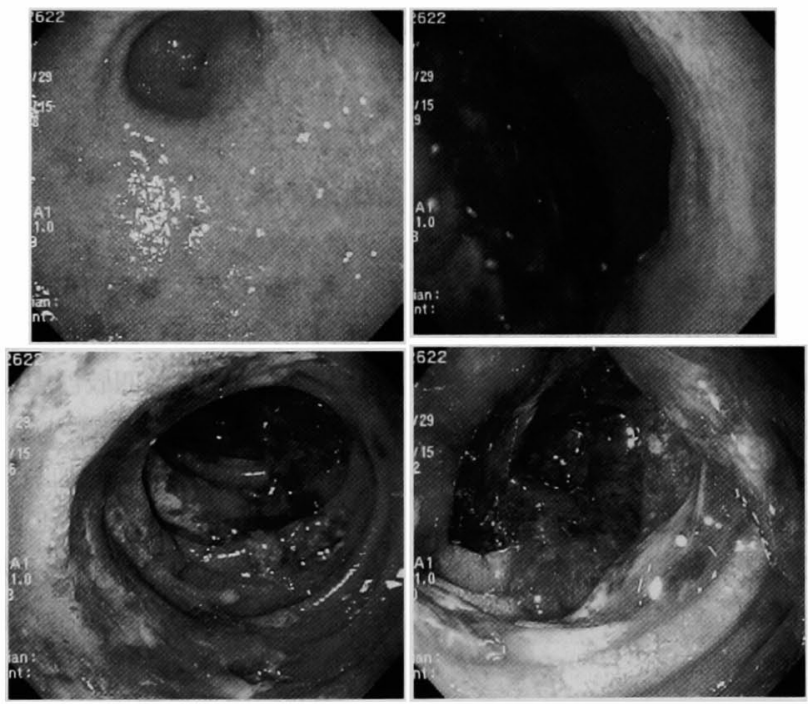

図 1 上部消化管内視鏡検査（初診時）：a， b ）胃に軽度のびら ん, 発赤が多発しており多量の残渣を認めた。 $\mathrm{c} ， \mathrm{~d})$ 十二指腸 は下行脚〜水平脚にかけて著明な発赤, 浮腫状変化を認め, びら ん・潰瘍が多発していた。 \begin{tabular}{l|l}
$\mathrm{a}$ & $\mathrm{b}$ \\
\hline $\mathrm{c}$ & $\mathrm{d}$
\end{tabular}

3 ). 十二指腸潰揚底および周囲の粘膜からの生検では 有意な所見は得られなかった. 入院12日目の腹部〜骨 盤部 CT 検查では小腸の壁肥厚はわずかに軽快してい たが炎症性と思われる腹水が出現していた（図 $2 \mathrm{c}$ ， d). 入院後時々黒色便は認めていたが, 入院13日目に 1 回目の大量下血が出現し, $\mathrm{Hb}$ は $5.3 \mathrm{~g} / \mathrm{dl}$ まで低下し た(図 4 ). 腹部〜骨盤部造影 CT 倹査を施行するも出
血点は同定できず輸血にて対処した，入院20日目に2 回目の大量下血が出現した。入院21日目に再度腹部 〜骨盤部 CT 検査を施行するもやはり出血点は同定て きず輸血にて対処した。入院23日目に 3 回目の大量下 血が出現した. 血管造影検査にて動脈瘤や狭窄像は認 めず, 回結腸動脈の回腸枝に血管の漏出像を認めた.

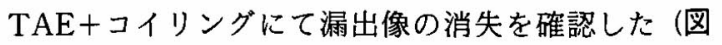



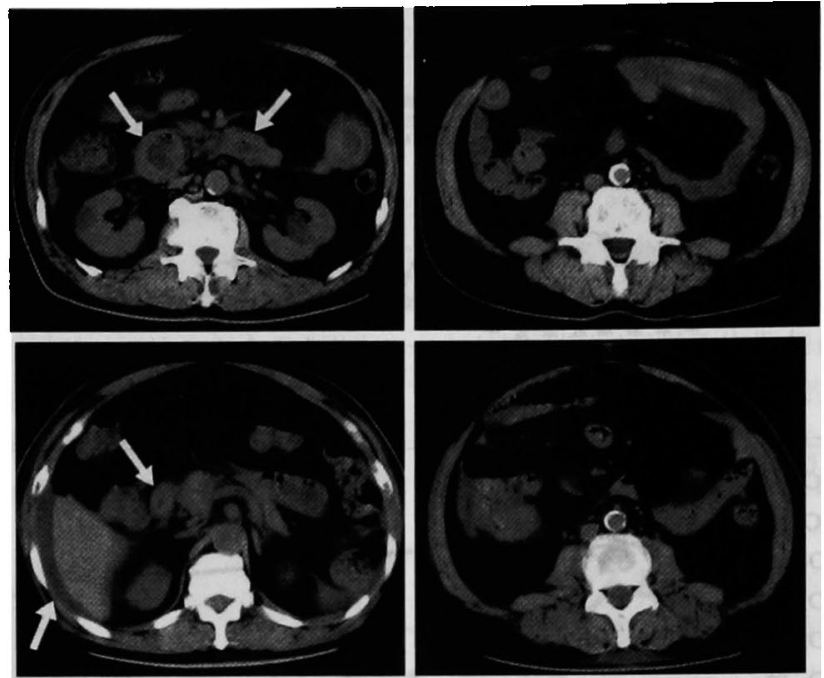

図 2 腹部 CT 検查 (入院後 4 日目 $\mathrm{a}, \mathrm{b}$ ，入院後12日目 $\mathrm{c}, \mathrm{d}$ ) : a ) 十二指腸全体に壁の肥厚を認めた（arrow）。 b ) 広汎に小腸の壁 肥厚を認めた。 c) 十二指腸の壁肥厚は改善を認めた（arrow）。 腹水の出現を㒛めた， d) 所々の小腸の壁肥厚も改善を認めた。

\begin{tabular}{l|l}
$\mathrm{a}$ & $\mathrm{b}$ \\
\hline $\mathrm{c}$ & $\mathrm{d}$
\end{tabular}
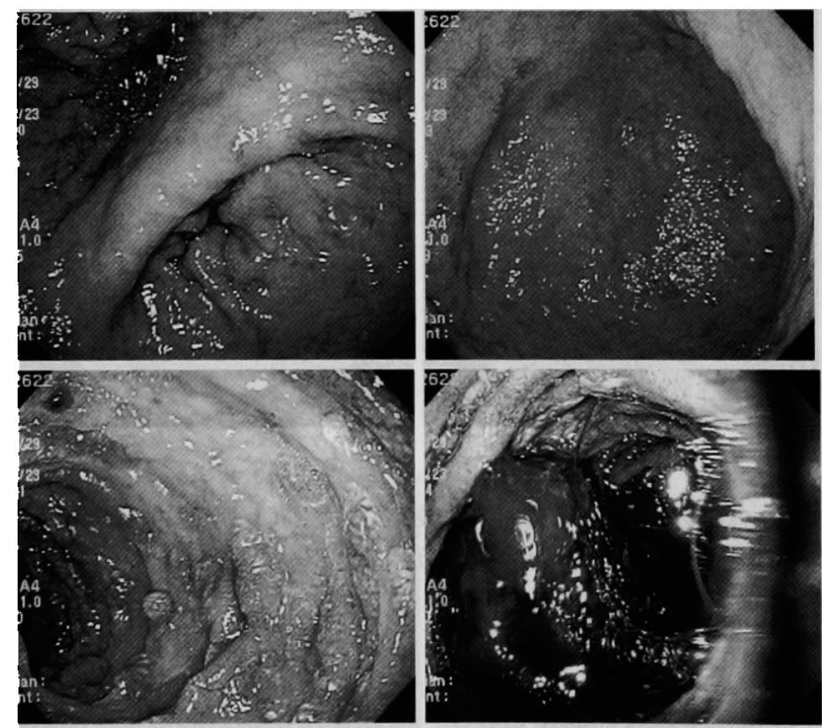

図 3 上部消化管内視笠検査 (入院後 9 日目)：a， b ) 胃に軽度の びらんの残存を認めた。c) 十二指腸下行脚にはびらん・謴場が 広がっていたものの出血は認めなかった，d）十二指腸水平脚に は凝血塊の残存を認めた。 \begin{tabular}{l|l}
$\mathrm{a}$ & $\mathrm{b}$ \\
\hline $\mathrm{c}$ & $\mathrm{d}$
\end{tabular} 


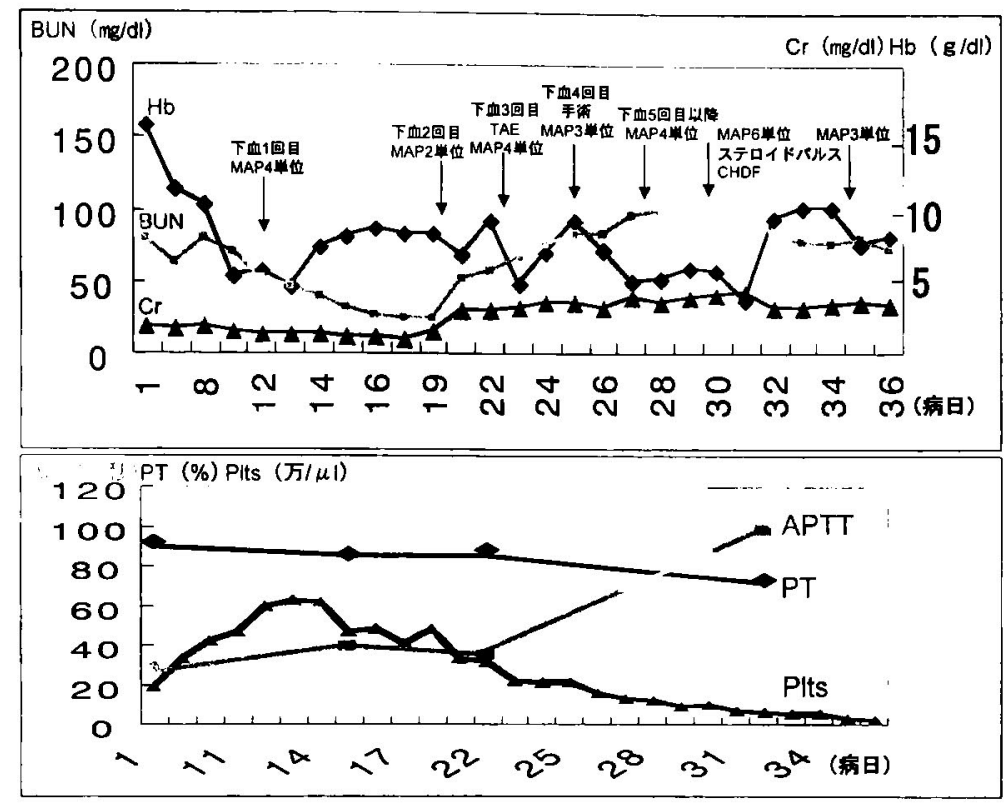

図 4 経過と血液検査データの推移：a ) Hb, BUN, Cr の推移と経過を示す， b) APTT, PT, 血小板の推移を示す.

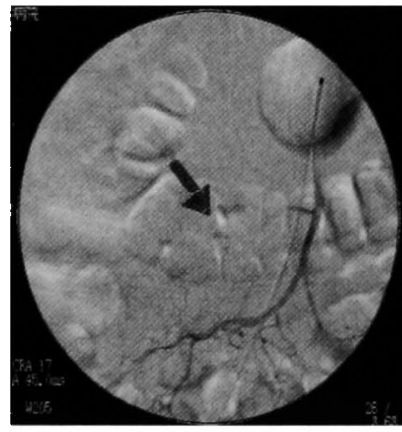

a

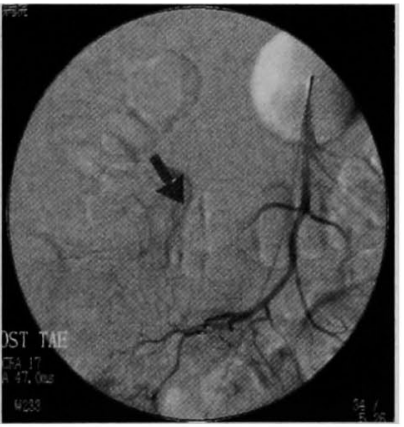

b

図 5 腹部血管造影検査（入院後23日目）：a）回結腸動脈の回腸 枝の末梢に造影剤の pooling を認めた. b) ゲルフォームで TAE を施行し coilingにて止血を認めた（arrow）.

5).しかし入院25日目に 4 回目の大量下血が出現し， 緊急手術を施行した。

手術所見：獎夜性の腹水を多量に認めた。また回腸 末端より約 $50 \mathrm{~cm}$ の回腸墏膜面に発赤を認めた（図 6 a ）。術中透視でその領域の腸間膜にコイルを確認し, コイルを含め回腸約 $15 \mathrm{~cm}$ を切除した。同部はほぼ全 域潰湯となっていたが明らかな露出血管は確認できな かった。同部での吻合は縫合不全の危険が高いと考え
術中内視鏡を行った。内視鏡では口側，肛門側ともび らん, 潰渲が50cm 以上にわたって広がっていた. 潰瘍 ができるだけ軽微な部位を確認し，さらに口側約 15 $\mathrm{cm}$, 肛門側約 $3 \mathrm{~cm}$ の回腸を追加切除し端々吻合を施 行した。

切除標本肉眼所見：回腸には全周性のびらんと地図 状の潰場形成を認めた（図6 b).

病理組織学的所見：U1-II までの浅い潰瘍が拡が 
り，粘膜下層から槳膜下層に拡がる fibrinoid necrosis を示す小動脈が散見された。内弾性板は断裂し，中膜 の fibrinoid necrosis を示すものが多くみられた.壊死 部では好中球の浸潤がみられ，いわゆる ArkinのII期 に相当する像を呈した結節性多発動脈炎と診断した (図 7)。

術後経過：術後レスピレーターにて呼吸管理を行い つつ加療するも, 入院27日目に 5 回目の下血が出現し た。輸血, 止血剤にて保存治療とした. 入院30日目, 病理診断を確認すると同時にステロイドパルス療法 (メチルプレドニゾロン $1000 \mathrm{mg} / \mathrm{day}$ を 3 日間連続投
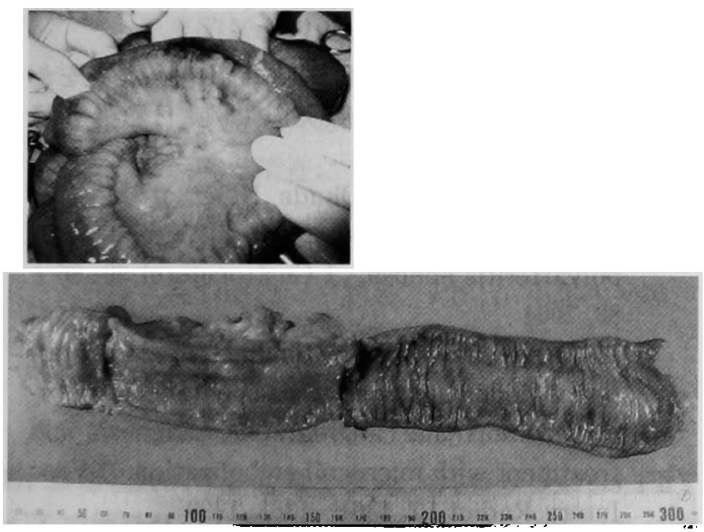

园 6 a 術中写真：回腸末端より約 $50 \mathrm{~cm}$ の回腸墏膜面に 発赤を認めた。

b 切除標本：最初に切除した回腸 (中央1/3) は全周 性にびらんし浮腫状で地図状の演場の形成を認めた。追 加切除した肛門側 (左 $1 / 3)$, 口側 (右1/3) も浮腫状て腸 間膜付着側を中心にびらん・漬崵を認めた。
与）を開始した。入院31日目，進行する腎不全に対し CHDF を開始した。しかし入院32日目，DICによりロ 腔内や鼻腔内からも出血が出現し，下血も止まらなく なり入院36日目（術後11日目）永眠された。

\section{考 察}

結節性多発動脈炎は全身の小・中径動脈を侵す壊死 性血管炎であるが，病変の首座が中型筋性動脈か毛細 血管かにより古典的結節性多発動脈炎 (classical PN ; 以下 CPN) と顕微鏡的多発動脈炎 (microscopic polyangitis：以下 MPA）に分類される。いずれも症状 は非特異的であり, MPA は MPO-ANCA（抗好中球 細胞質ミエロペルオキシダーゼ抗体）陽性により診断 されることもあるが, CPN の確定診断は血管造影で腹 部多発小動脈瘤および狭窄所見を認めるか，病理組織 学的検查で証明されなければならない5．通常の場合， 生検は腎や皮有で行われることが多い，PN 患者のう ち何らかの腹部症状を呈するものは $30 〜 60 \%$ と言われ ており，MPAょりCPNに多い傾向がある。CPNの 主要症状は発熱, 高血圧, 進行性の腎不全, 多発性単 神経炎, 関節炎, 筋肉痛, 消化管出血, 皮店症状など であるが, 初発症状が消化管病変であることは $3 \sim 6$ \%と少ない.さらに消化管内視鏡下での生検組織から は確定猃断は困難といわれているため6)，消化管出血 が主症状の CPN を術前や生存中に確定診断すること は容易ではない。

$\mathrm{CPN}$ の消化管病変に対する治療は基本的に CPN の治療に準じステロイドや免疫抑制剤の使用である が, 出血性病変の場合には内視鏡的止血術や血管造影 下の塞栓術, あるいは開腹手術を先行しなければなら ないことがある。

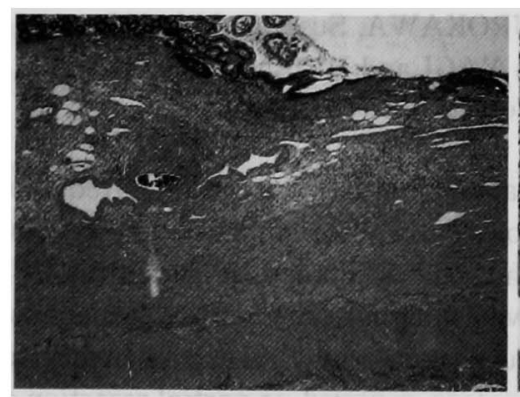

a

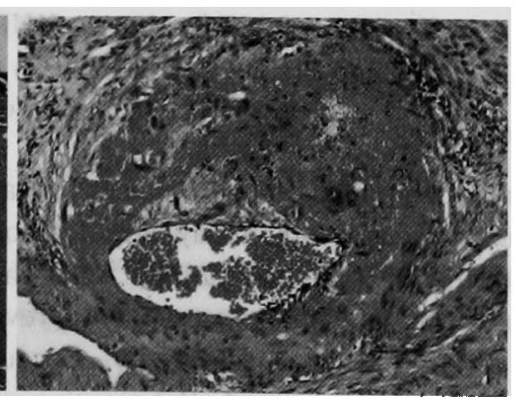

b

図 7 病理組織学的検査：a)UI-IIまでの浅い潰瘍が拡か゚り, 潰瘍底には幼若な肉 芽組織の增生がみられる。粘膜下層から漿膜下層に拡がる fibrinoid necrosis を 示す小動脈が散見される $(\mathrm{HE} \succ 4)$ ， b ) 内弾性板は断裂し，中膜の fibrinoid necrosis がみられる $(\mathrm{HE} \times 200)$. 
本症例では消化管出血に对し診断・治療を目的にも っと早急に血管造影下の塞栓術を施行するべきであっ たのかもしれないが，上部消化管内視鏡で十二指腸か らびらん，演瘍，凝血塊のあることが明らかであり， CTで広範な小腸の壁肥厚を認めていたことから出血 源が広範囲であると予測され, 血管造影下の塞栓術は 第一選択となりにくい状況であった．その結果開腹手 術へ踏み切る時期にも遅れを生じた。実際に塞栓術や 開腹手術の後も消化管出血は再燃し, 出血源は十二指 腸から回腸末端までの広範囲にわたるものであり, 出 血はコントロール不能であった。手術の切除標本によ り確定診断を得てステロイド・パルス療法を開始した が，進行する腎不全とコントロール不能の消化管出血 により DICに陥り救命しえなかった。

剖検では十二指腸から回腸に至るびらんを認めた が，胃・大腸には壊死性血管炎の所見はみられなかっ た．脾蔵の実質の一部の小動脈に壊死性血管炎を認め たが,堅藏などの諸臓器には血管炎はみられなかった。 よって急速な腎不全の進行は原疾患よりもコントロー ル不能の出血と大量の輸血が原因であった可能性が高 いと考えられる.PN の確定診断に腎生検が行われる こともあるが本症例では腎缄の血管炎は明らかでな く,腎生検では確定診断に至らなかったと考えられる。 結果的には確定診断を得るためにも治療のためにも消 化管の切除は避けられなかったであるう。

結節性多発動脈炎の消化管症状による下血を疑った 場合, 止血と診断を目的として早急に血管造影や塞栓
術を行うべきであり，手術による切除も十分考慮に入 れておく必要があると考える. 現時点ではステロイド および免疫抑制凨の併用療法もしくはステロイドパル ス療法による治療が寬解導入, 維持に最も有効であり, 本疾患と診断されたら早急にそれらの治療を開始する べきである。

\section{結論}

治療抵抗性の出血性腸炎に遭遇した場合, 結節性多 発動脈炎などの血管炎の可能性を念頭におき，より早 期の診断および治療を行うことが肝要と考えられた。

\section{文 献}

1）高田知明, 吉田秀明, 塚田守雄他：急性腹症で発 症した古典的結節性多発動脈炎の 1 例. 日消外会 誌 $36: 51-56,2003$

2）仲 至永, 吉川 澄, 江本 節他：小腸壤死をき たした結節性多発動脈炎の 1 例. 日臨外会誌 $63: 2697-2700,2002$

3) Tanabe J, Abe T, Okada $N$, et al: Massive gastrointestinal bleeding in a patient with polyarteritis nodosa. J Gastroenterol $39: 86-$ 88,2004

4) Allen AW, Waybill PN, Singh H, et al : Polyarteritis nodosa presenting as spontaneous perirenal hemorrhage: angiographic diagnosis and treatment with microcoil embolization. J Vasc Interv Radiol $10: 1361-1363,1999$

5）尾崎承一：結節性多発動脈炎の診断基準・重傷度. 内科 $95: 1460-1464,2005$

6）松本啓志，古賀秀樹，飯田三雄他：結節性多発動 脈炎. 胃と腸 $38: 529-534,2003$

\title{
A CASE OF POLYARTERITIS NODOSA CAUSING UNCONTROLLED GASTROINTESTINAL BLEEDING
}

\author{
Kenichiro SAITO, Masaru KUROKAWA, Susumu AMAYA, \\ Kazushige SHIBAHARA, Shingo YAGI and Hiroshi HASEGAWA \\ Department of Surgery, Toyama Red Cross Hospital
}

\begin{abstract}
A 65-year-old man complaining of nausea and abdominal fullness was admitted to our hospital. An upper gastrointestinal endoscopic study revealed consecutive erosion, ulcer and bleeding in the second portion of the duodenum. Abdominal CT scan showed widespread inflammation of small intestine. Endoscopic biopsy from duodenal mucosa did not reveal a definite diagnosis. After admission, the patient passed massive blood in his stool repeatedly. Because angiography revealed bleeding from a branch of iliocolic artery, TAE was performed. But massive melena recurred, so partial resection of the ileum was performed. The pathological diagnosis was polyarteritis nodosa. Although steroid pulse therapy and CHDF for renal failure were begun, melena recurred and the patient died. In a case of uncontrolled hemorrhagic enteritis, arteritis including PN must be taken into account for rapid diagnosis and proper therapy.
\end{abstract}

